DOI: $10.2478 / \mathrm{v} 10025-010-0020-\mathrm{y}$

JOURNAL OF WATER

AND LAND DEVELOPMENT

J. Water Land Dev. No. 13a, 2009: 71-84

\title{
Potential water retention capacity of forest areas - an example of the Experimental Forest Range Unieszów
}

\author{
Sylwester GRAJEWSKI, Anna KRYSZTOFIAK, Antoni T. MILER
}

University of Life Sciences in Poznań, Department of Forest Engineering, ul. Mazowiecka 41, 60-623 Poznań, e-mail: sylgraj@up.poznan.pl, annakrysztofiak@wp.pl, amiler@up.poznan.pl

\begin{abstract}
The paper presents a proposal to describe potential water retention capacity of a given area, not necessarily the catchment basin, by a single parameter that would reflect all significant nonclimatic physico-geographic characteristics. The potential retention capacity of forest areas in this method is estimated based on subdivision area i.e. the area of the smallest spatial unit in forestry to which a single parameter representing combined effect of physico-geographic factors of the region is attributed. In this way, characteristics assumed to be decisive for potential water retention capacity were assigned to each subdivision. Ranges of variability of each parameter were then divided into three classes (coded 1, 2 and 3) respectively to small, medium and large potential retention capacity. In the next step the codes of all parameters attributed to each of the subdivisions were summed up to obtain new value reflecting their water retention capacity. The last stage was the generation of a map presenting spatial variability of calculated index. Created map shows considerable spatial variability of the index. Subdivisions of small and of large capacity are dispersed all over the object without any tendency of combining into larger patches. Results of this study may serve as a basis to assess water relations, to establish water management priorities in plans of forest or spatial management.
\end{abstract}

Key words: Experimental Forest Range Unieszów, index of potential retention capacity, water retention

\section{INTRODUCTION}

All decisions associated with environmental management require collection of much information on this environment. This paper presents a method of estimating the index of potential water retention capacity of forest areas illustrated by one forest range in the Experimental Forest Inspectorate Siemianice. Knowledge of spatial distribution of this index, which is a static characteristic of retention, might enable objective assessment of potential water retention capacity of a given area, might help compare different objects or be a basis for possible transfer of hydrologic information from monitored to uncontrolled objects. 
Maps of potential retention capacity may be used in the assessment of water relations, in formulating recommendations for water management in forest management plans and in planning actions aimed at increasing the efficiency of water retention in a given object.

\section{AIM AND RANGE OF THE STUDY}

The study was undertaken to present a concept of estimating the index of water retention capacity of forest areas calculated from unit area of a forest subdivision and to determine its spatial variability in the Experimental Forest Range Unieszów - a part of the Experimental Forest Inspectorate Siemianice of the University of Life Sciences in Poznań.

Analyses were based on: forest farm management statement (Operat..., 2005), cartographic materials (Mapa przeglądowa..., 1994; Mapa topograficzna..., 1997; Mapa hydrograficzna..., 1998-2000) and databases attached to digital map of the Experimental Forest Inspectorate Siemianice (Operat..., 2005).

\section{METHODS}

Potential retention capacity of an area is a resultant of its non-climatic physico-geographic properties (land use, land relief, river network, standing waters etc.). It would seem obvious to describe the capacity with multiple regression equation with appropriate non-climatic physico-geographic parameters as independent variables. Unfortunately, these parameters are interrelated which makes such a way impossible. We propose here to attribute one index to a given area, not necessarily the catchment basis. The index would be a measure of water retention capacity reflecting the impact of all significant non-climatic physico-geographic characteristics.

The idea of calculating water retention capacity for river catchments was already presented in the literature (MILER, 1984; 1994; 1998; MILER et al., 2001). Main assumption of the method proposed here is to use the area of a subdivision (the smallest unit area in spatial division of forests) to estimate the index of potential retention capacity of forest areas. It requires assigning characteristics decisive for potential retention capacity to each of the subdivisions (GRAJEWSKI, 2006; KRYSZTOFIAK, 2008). The following characteristics were proposed for the whole area of the Experimental Forest Inspectorate Siemianice in earlier papers (KRYSZTOFIAK and GRAJEWSKI, 2007; KRYSZTOFIAK, 2008):

1. Mean slope of the area, \%o;

2. Variant of habitat moisture (-);

3. Distance from the river network, m; 
4. Distance from standing waters (lakes, ponds), $\mathrm{m}$;

5. Mean weighed coefficient of soil filtration, $\mathrm{mm} \cdot \mathrm{s}^{-1}$;

6. Index of tree stand density $(-)$;

7. Type of soil cover (-);

8. Age of the tree stand, years;

9. Type of forest habitat (-);

10. Tree species dominating in the tree stand (-).

Ranges of the values of each parameter were divided into three classes (coded 1, 2 and 3) respectively to small, medium and large potential retention capacity.

Mean slope of the area. It was calculated individually for each subdivision acc. to the equation:

$$
I=\frac{\Delta H}{\sqrt{P}}
$$

where:

I $\quad-$ mean slope of the area in the subdivision, \%;

$P \quad$ - surface area of the subdivision, $\mathrm{km}^{2}$;

$\Delta H$ - difference between the highest and the lowest ordinate in a given subdivision, $\mathrm{m}$.

Slopes in subdivisions were adopted from the mean slope of the area in particular divisions to which they belonged. Range of the mean slopes (from 0.41 to 59.19\%o) was divided using Strzemski's slope classification in relation to surface inclination (STRZEMSKI et al., 1973).

Variant of habitat moisture. Degrees of moisture were coded according to the relationship - the drier the habitat the less its retention capacity.

Distance from the river network means the shortest length of a section joining the subdivision's border with the closest natural or artificial watercourse.

Distance from standing waters (lakes, ponds) was adopted as the length of a section joining subdivision's border with the closest natural or artificial water body of an area not less than 0.25 ha.

Mean weighed coefficient of soil filtrations was established based on the soil type in a subdivision given in Operat... (2005) and coefficients of filtration of soil formations adopted after Flisowski (FILISOWSKI et al., 1986). Thicknesses of particular soil layers in the profile served as weights.

Index of tree stand density is estimated in forest inventories in the fourdegree scale: full cover, moderate, interspaced and loose. The classification was supplemented by the category - no cover. Then, the ratio of tree crowns' projection to the area occupied by that tree stand was calculated and the ratios were assigned to particular categories as follows: 0.92 - full cover, 0.80 - moderate, 0.65 - interspaced, 0.40 - loose and $0.00-$ no cover (WŁOCZEWSKI, 1968). The index for the 
whole tree stand was calculated as a sum of tree densities in the I and II forest store.

The type of soil cover - literature data (e.g. GUTRY-KORYCKA, 1989; SULIŃSKI, 1993; CEBULSKA and OSUCH, 1998; HOMA, 1998) were used to estimate numerical values of this parameter assuming classification and nomenclature as in Instrukcja... (1994).

The age of tree species dominating in a tree stand was adopted as the age of this tree stand.

Type of forest habitat - was established for each subdivision based on Operat... (2005).

Tree species dominating in the tree stand. Division into coniferous species (code 3) and deciduous species (code 1) was adopted. Code 2 was not assigned.

Table 1. Coding of parameters that describe potential water retention capacity for forest subdivisions

\begin{tabular}{|c|c|c|c|c|c|}
\hline \multirow{2}{*}{ No. } & \multirow{2}{*}{ Parameter } & \multirow{2}{*}{ Unit } & \multicolumn{3}{|c|}{ Codes } \\
\hline & & & 1 & 2 & 3 \\
\hline 1 & Mean slope of the area & $\%$ & $>52$ & $36-52$ & $<36$ \\
\hline 2 & $\begin{array}{l}\text { Variant of habitat mois- } \\
\text { ture }\end{array}$ & - & $\begin{array}{l}\text { fresh, moderately } \\
\text { fresh, strongly } \\
\text { fresh }\end{array}$ & $\begin{array}{l}\text { moderately moist, } \\
\text { moist, strongly moist }\end{array}$ & $\begin{array}{l}\text { drained wet, } \\
\text { wet, very wet, } \\
\text { bog }\end{array}$ \\
\hline 3 & $\begin{array}{l}\text { Distance from the water- } \\
\text { course network }\end{array}$ & $\mathrm{m}$ & $<51$ & $51-200$ & $>200$ \\
\hline 4 & $\begin{array}{l}\text { Distance from standing } \\
\text { water (ponds and lakes) }\end{array}$ & $\mathrm{m}$ & $>200$ & $51-200$ & $<51$ \\
\hline 5 & $\begin{array}{l}\text { Coefficient of soil filtra- } \\
\text { tion }\end{array}$ & $\mathrm{mm} \cdot \mathrm{s}^{-1}$ & $>0.03$ & $0.03-0.10$ & $<0.010$ \\
\hline 6 & Tree stand density index & - & $<0.41$ & $0.41-0.79$ & $>0.79$ \\
\hline 7 & Type of soil cover & - & bare, forest litter & $\begin{array}{l}\text { herbaceous plants, } \\
\text { sward }\end{array}$ & $\begin{array}{l}\text { heavily grass } \\
\text { covered, moss }\end{array}$ \\
\hline 8 & Age of tree stand & years & $<21$ & $21-80$ & $>80$ \\
\hline 9 & Forest habitat type & - & $\begin{array}{l}\text { fresh coniferous } \\
\text { forest, fresh } \\
\text { mixed coniferous } \\
\text { forest }\end{array}$ & $\begin{array}{l}\text { wet mixed coniferous } \\
\text { forest, fresh mixed } \\
\text { deciduous forest, wet } \\
\text { mixed deciduous } \\
\text { forest, fresh broad- } \\
\text { leaved forest, wet } \\
\text { broadleaved forest }\end{array}$ & $\begin{array}{l}\text { alder/ash-alder } \\
\text { swamp forest, } \\
\text { riparian forest }\end{array}$ \\
\hline 10 & $\begin{array}{l}\text { Tree species dominating } \\
\text { in tree stand }\end{array}$ & - & deciduous & - & coniferous \\
\hline
\end{tabular}

In general, coding was assigned on the following assumptions:

- small potential water retention capacity of a given subdivision (code 1) was equated with high slopes, dry variant of habitat moisture, small distances from river networks, long distances from water reservoirs, high coefficients of soil fil- 
tration, low tree stand density, bare soils, young tree stands, dry coniferous habitats and deciduous tree species.

- large potential retention capacity of a given subdivision (code 3) was equated with low slopes, boggy habitat moisture, long distances from river networks, small distances from standing water bodies, low values of soil filtration coefficient, high tree stand density, moss soil cover, mature tree stands, bog and riparian habitats and coniferous tree species.

A map of spatial distribution over the study object was made for each characteristic (Figs 1 to 10). In the next step codes of all parameters attributed to each subdivision were summed up to obtain the index of potential water retention capacity for every subdivision. The last stage was to generate the map presenting spatial variability of calculated index (Fig. 11).
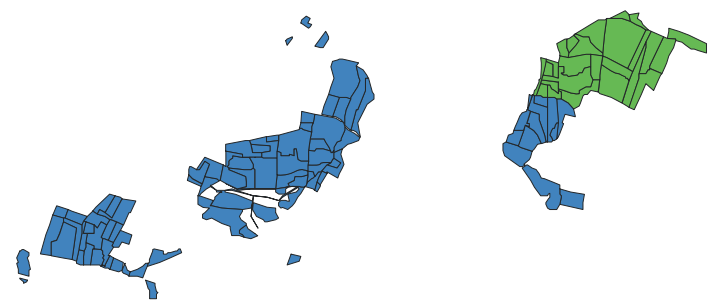

7

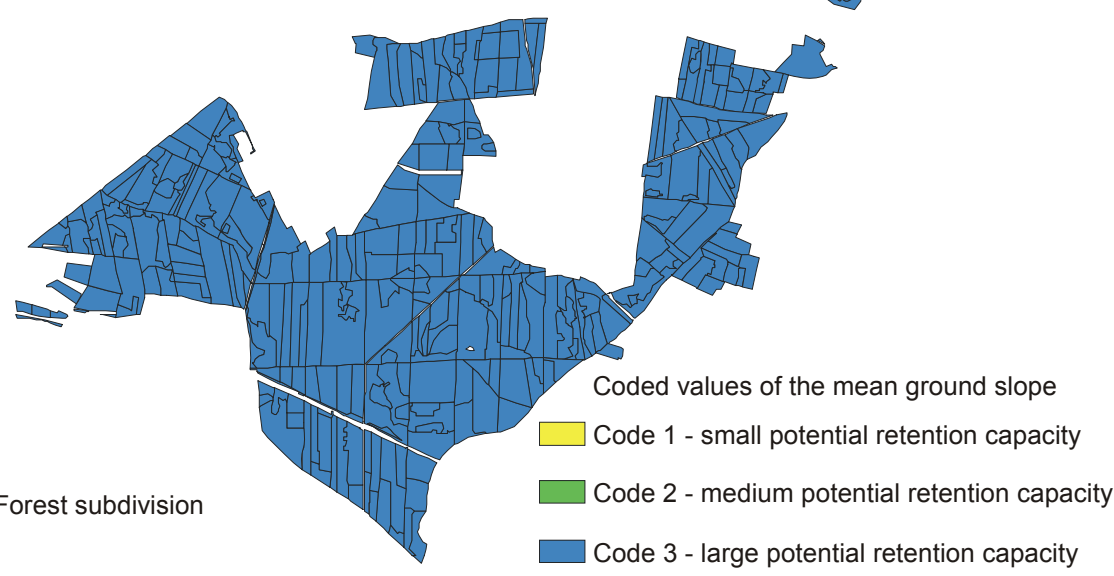

Fig. 1. Map of the codes for mean ground slopes 

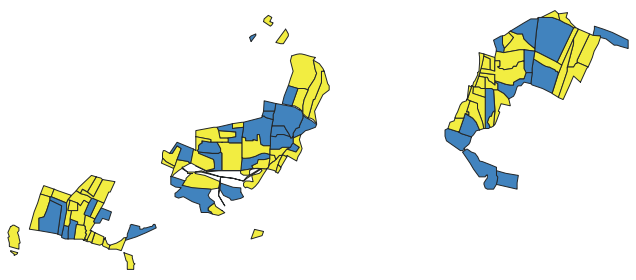

7

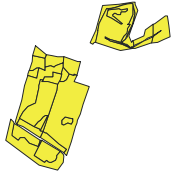

Forest subdivision

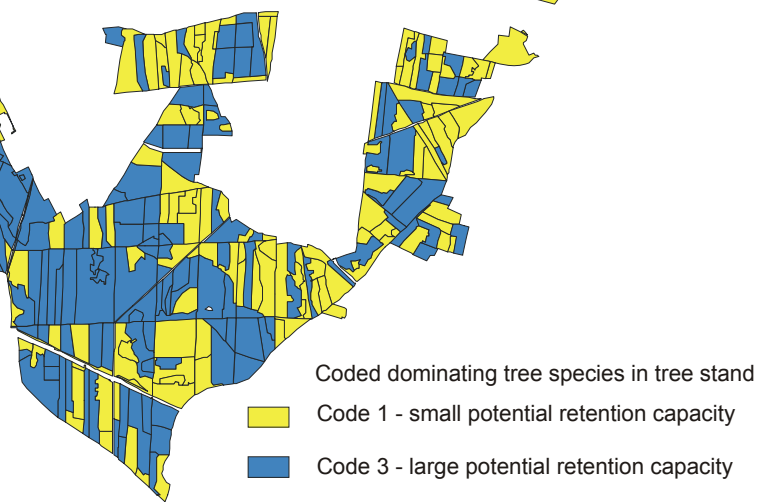

Fig. 2. Map of the codes for tree species dominating in tree stand
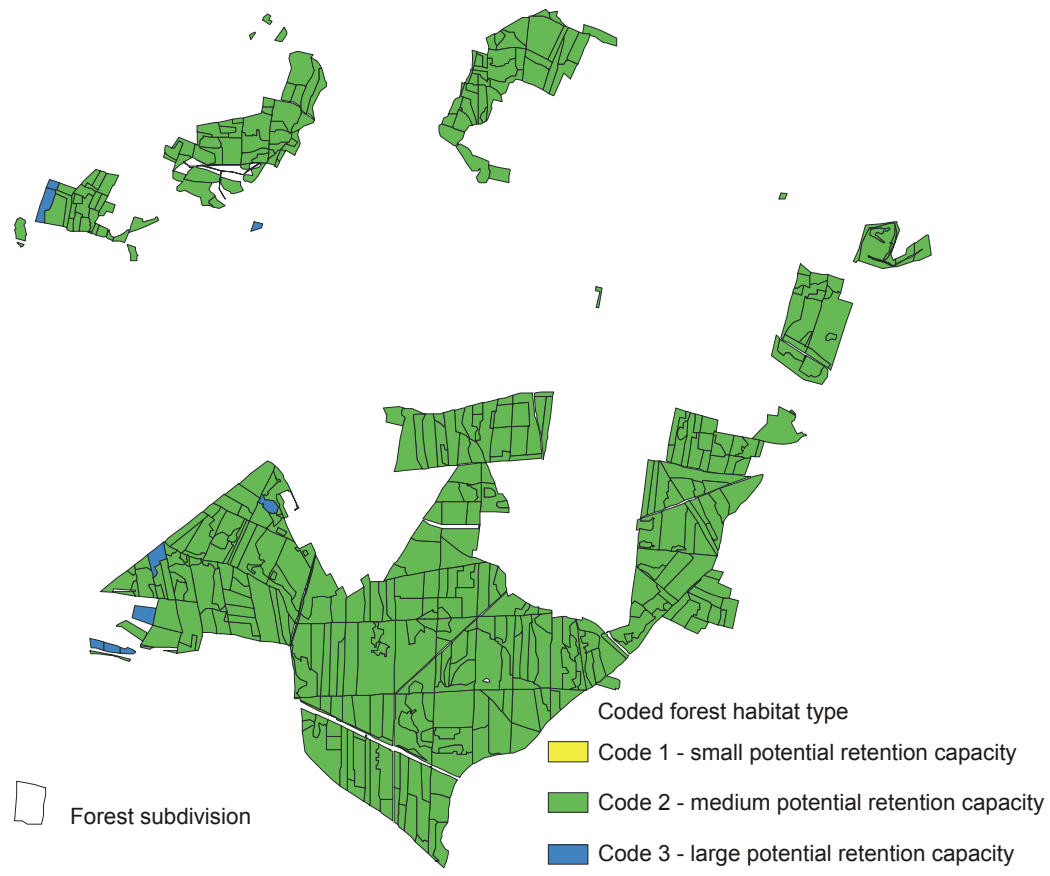

Fig. 3. Map of the codes for forest habitat types 


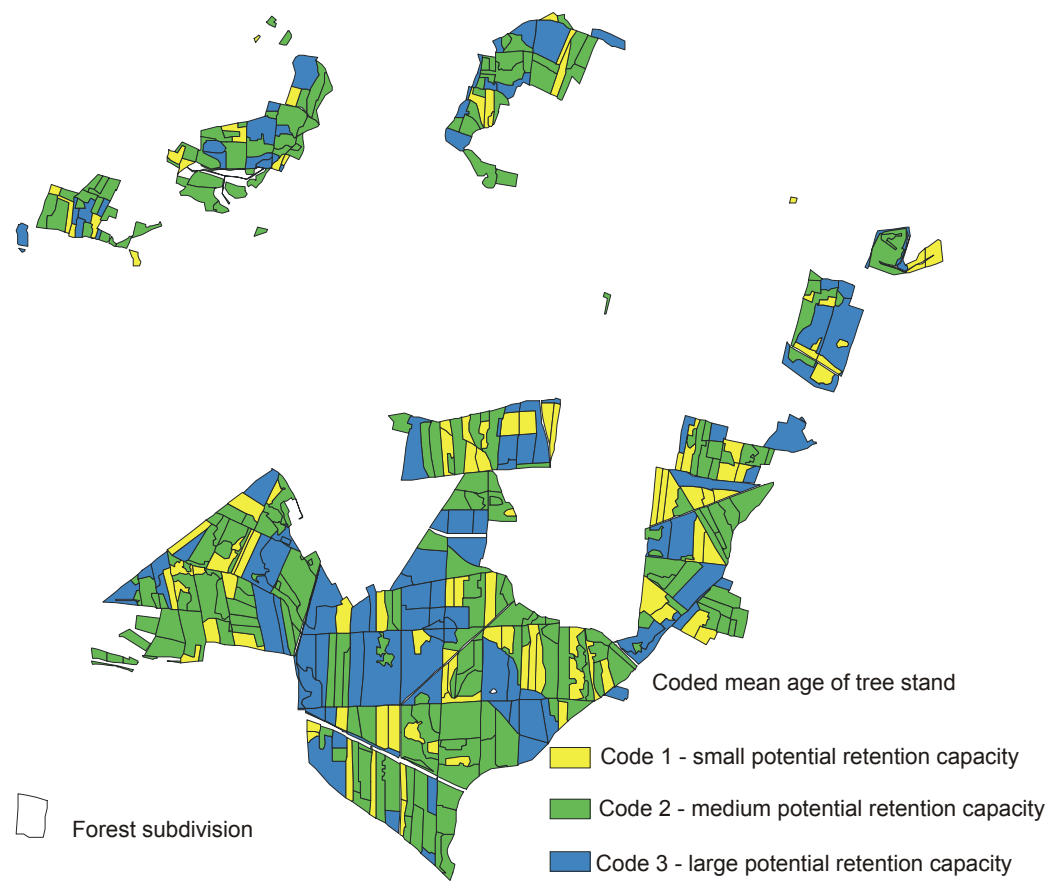

Fig. 4. Map of the codes for mean age of tree stands
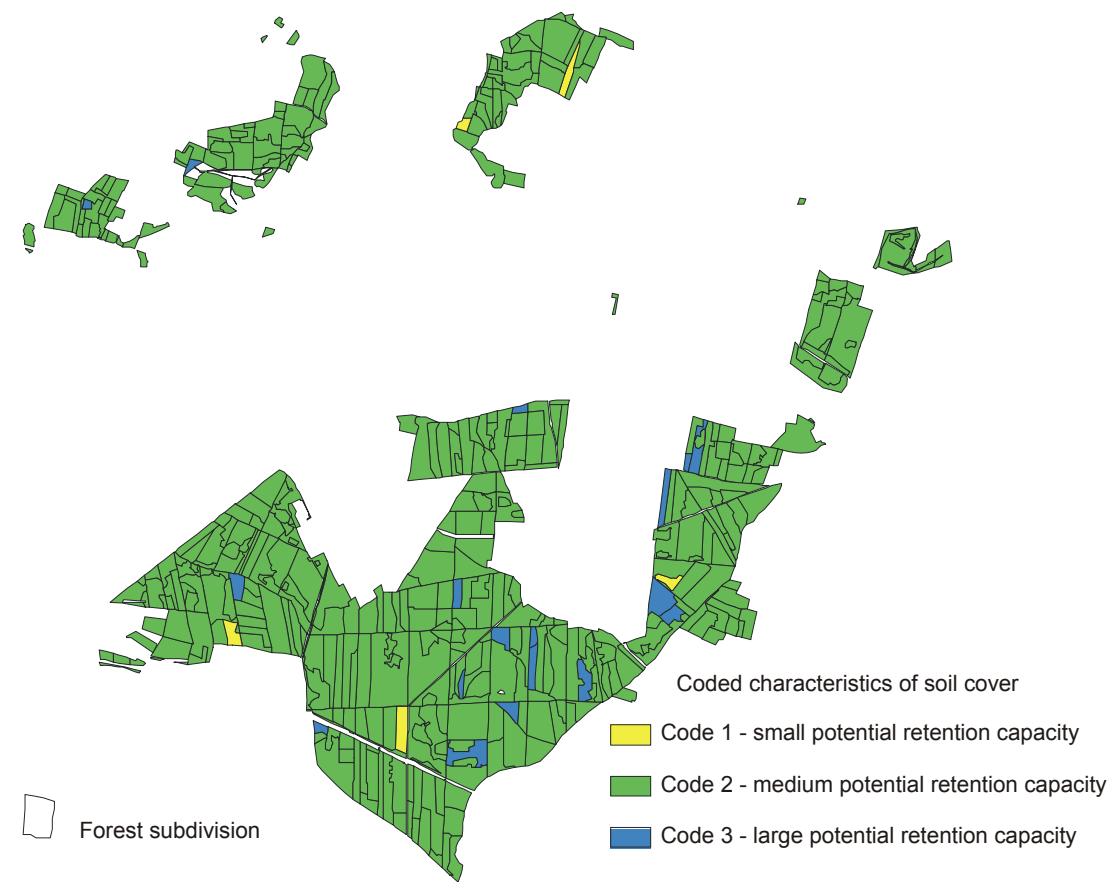

Fig. 5. Map of the codes for soil cover 

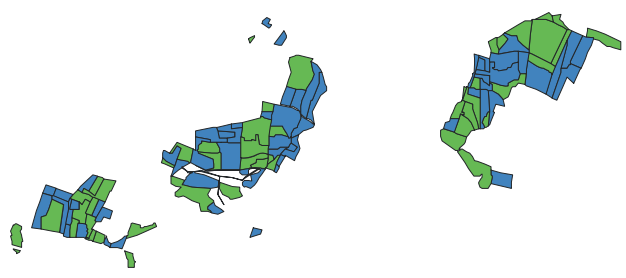

7
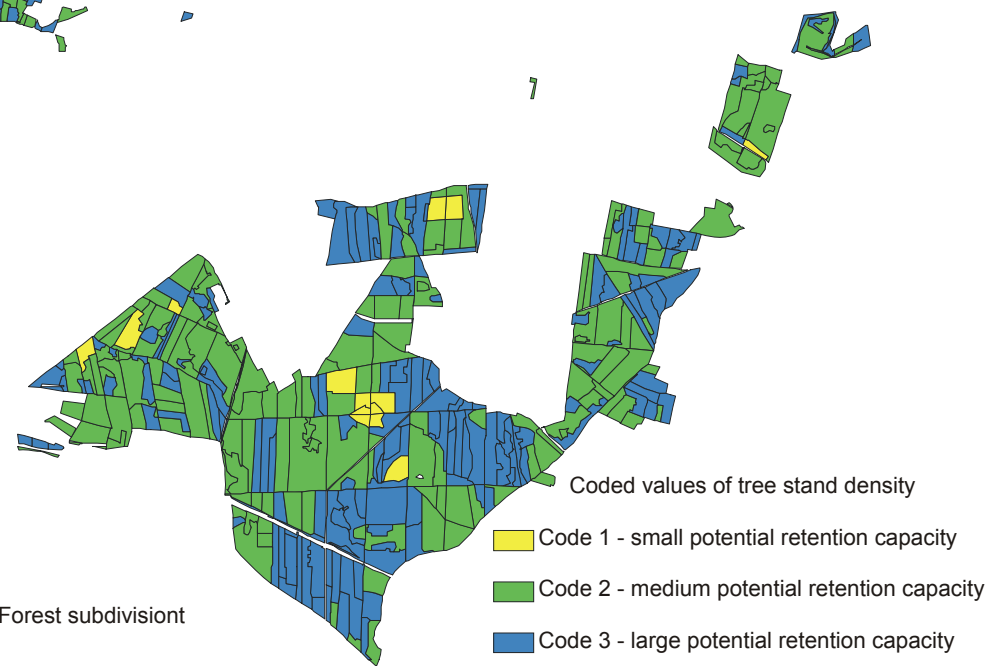

Fig. 6. Map of the codes for tree stand density
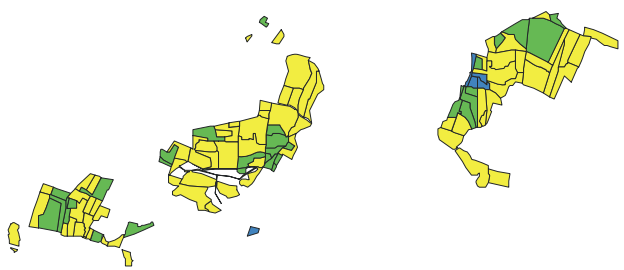

7
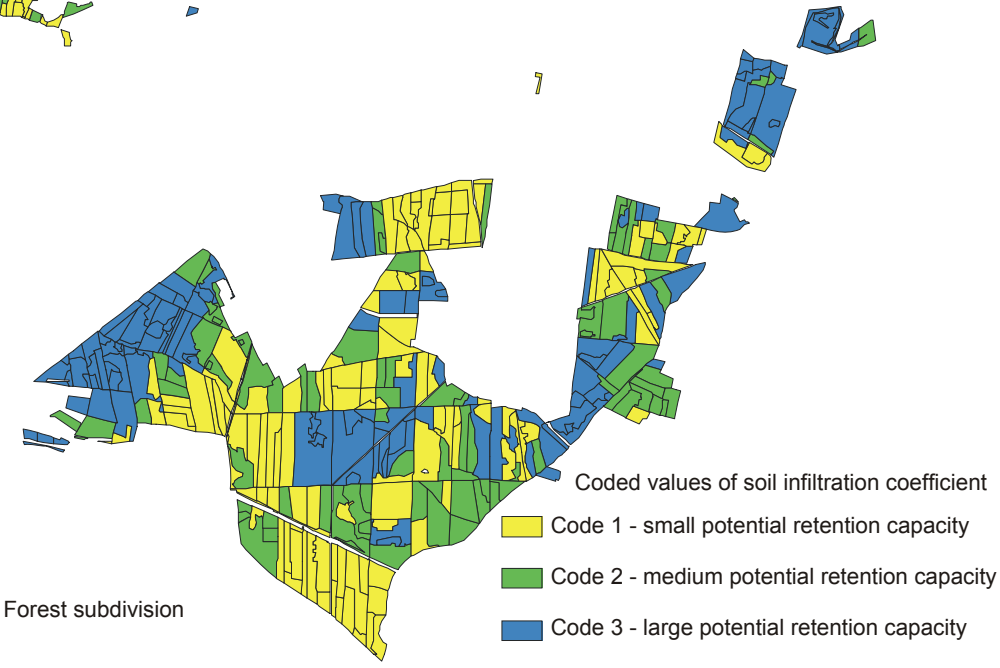

Fig. 7. Map of the codes for soil filtration coefficient 


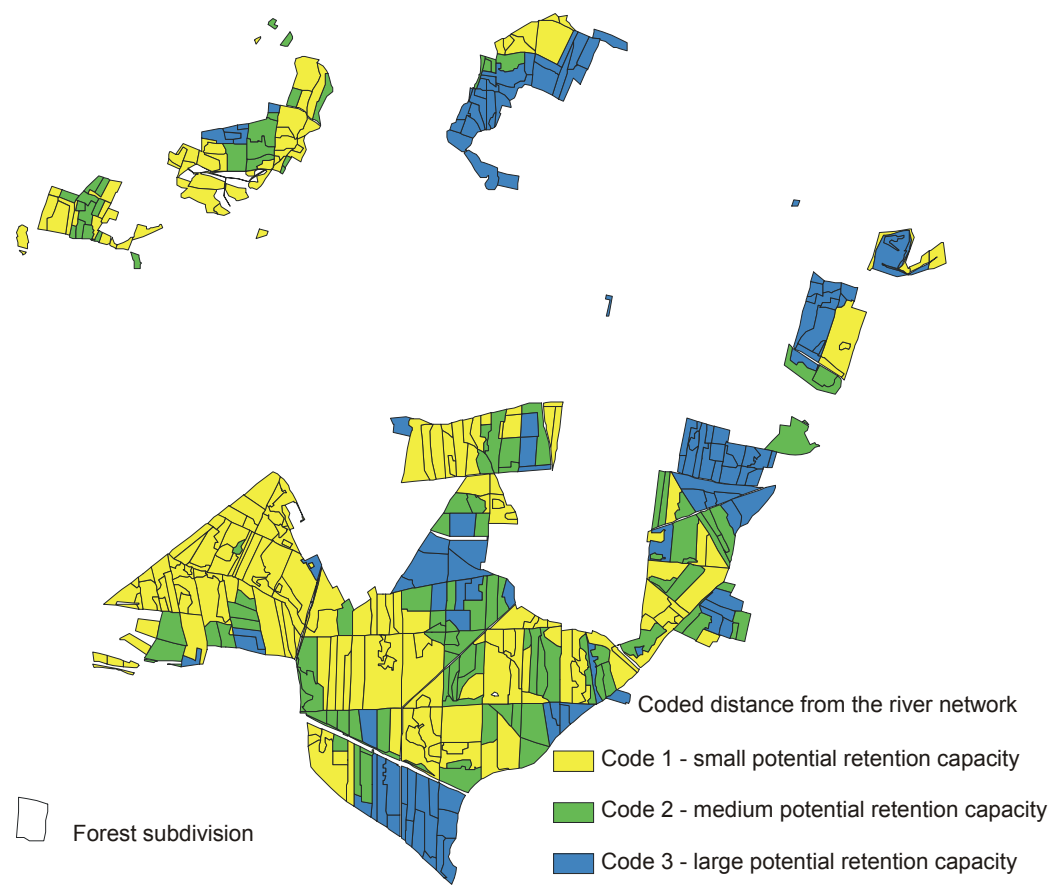

Fig. 8. Map of the codes for the distance from river network

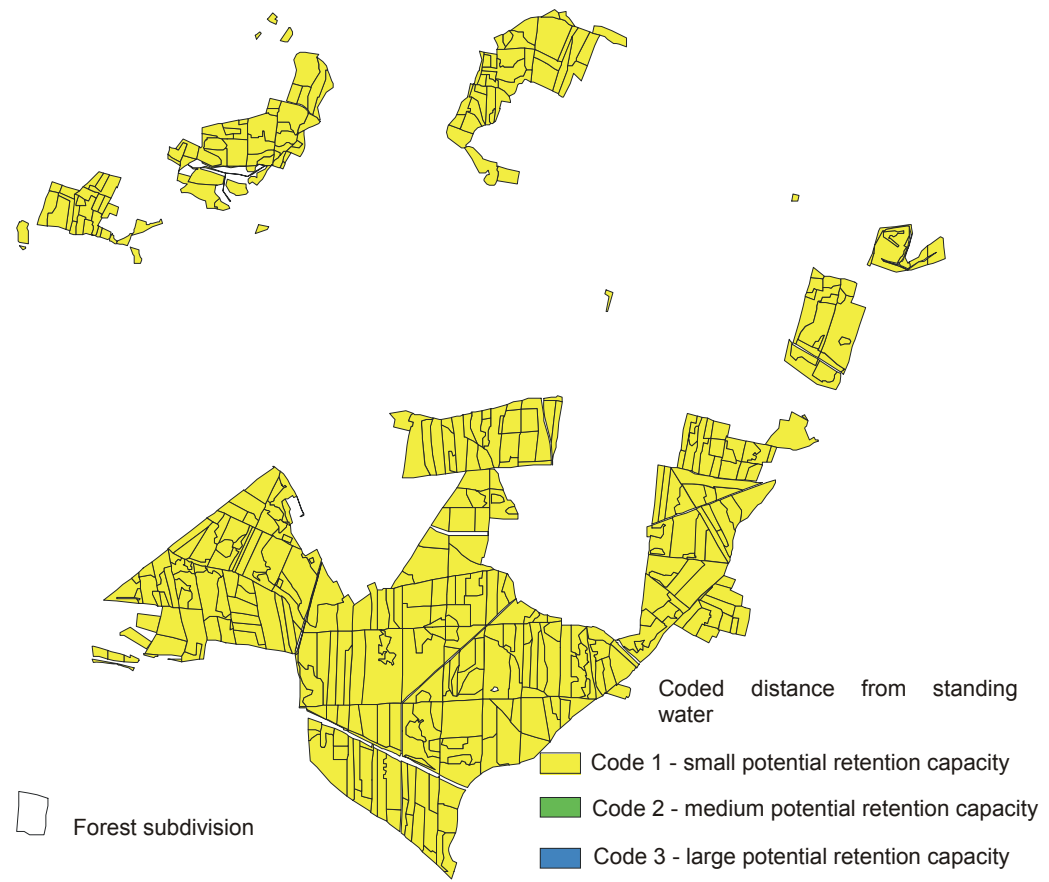

Fig. 9. Map of the codes for the distance from standing water bodies (ponds and lakes) 

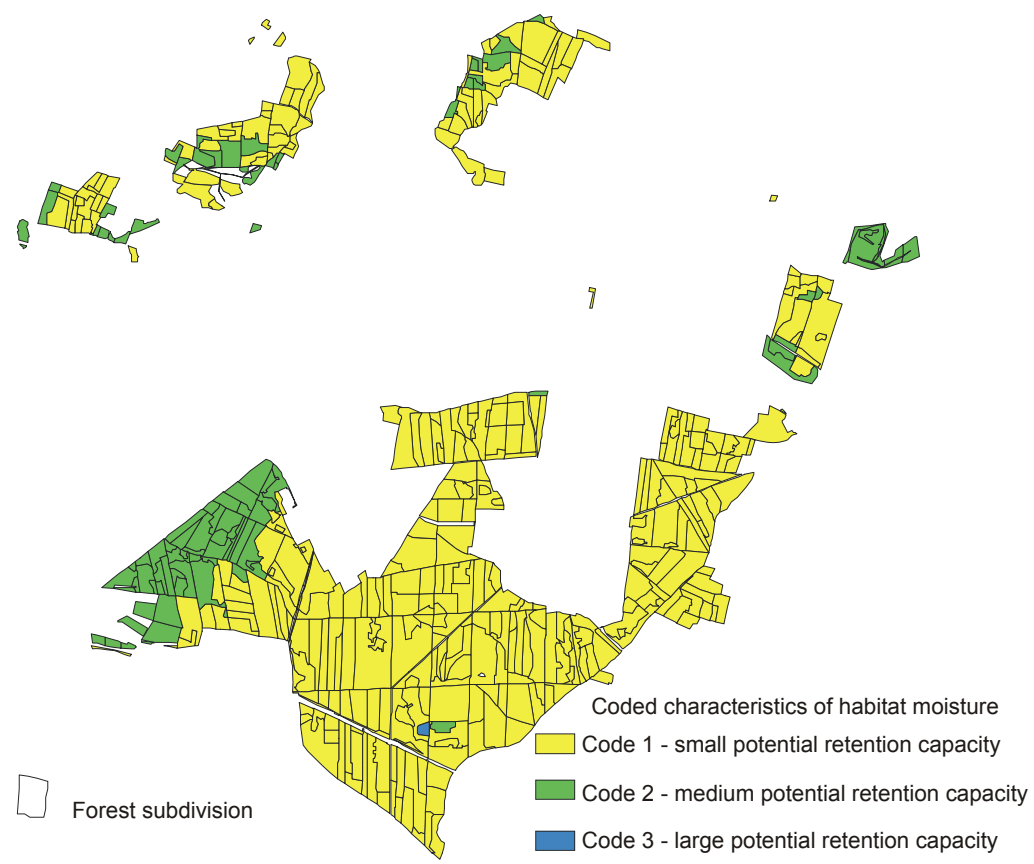

Fig. 10. Map of the codes for habitat moisture
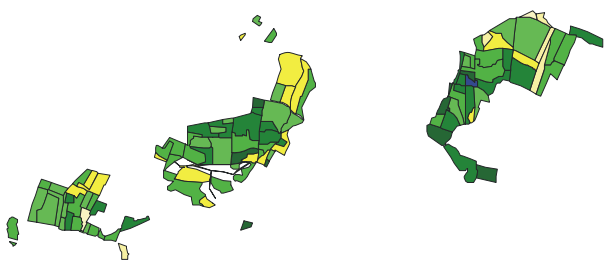

7
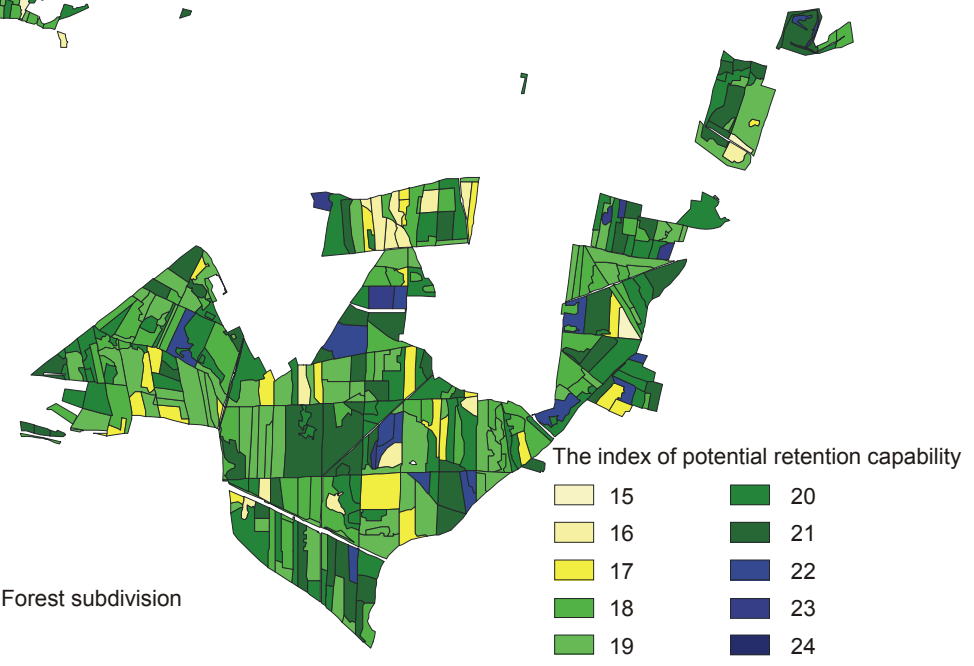

Fig 11. Distribution of the index of potential retention capacity of forest areas in the Experimental Forest Range Unieszów 


\section{RESULTS AND DISCUSSION}

The values of 10 characteristics typical for each of the unit areas (subdivisions) and decisive for water retention capacity of forest areas were the input data to estimate the index of potential retention capacity in the Experimental Forest Range Unieszów. All calculations were performed in agreement with the procedure presented above.

Specific character of the study area caused that some adopted parameters after coding showed no (distance from water bodies - Fig. 9) or relatively small (mean slope - Fig. 1, type of forest habitat - Fig. 3) spatial variability. In such cases the parameters do not affect or negligibly affect the spatial distribution of the index of potential retention capacity.

Distribution of the index of potential retention capacity in the Experimental Forest Range Unieszów was highly variable. The subdivisions of small and large capacity were dispersed over the whole object without any tendency to cluster into larger patches. One might only expect that larger clusters of areas of small or large potential retention capacities should be visible in the analysis of larger forest complexes like forest inspectorates, landscape parks, forest promotional areas etc.

\section{SUMMARY}

Characteristics of forest ecosystems may be relatively easily acquired and calculations may be performed easier through direct use of information contained in databases of the object in question. Basing on subdivision as a unit area may noticeably accelerate calculations and increase precision of estimates not only in quantitative aspect but also with respect to spatial localisation then when using raster (square plot) elementary area.

The idea of calculating the index of potential retention capacity (static retention characteristics) presented here may enable objective assessment of retention capacity of a given area, may give a possibility of comparisons between different areas and finally may be a basis for the transfer of hydrologic data from monitored objects onto those out of hydrometric control.

Obtained maps of the object with marked areas of small, medium and large potential water retention capacity may be a basis for assessing water relations, for setting up the priority of water management activities in the plans of forest management and for planning actions to increase the efficiency of water retention in a given object (creation of small water retention). These actions might have various characters like e.g. water reclamations or phytoreclamations.

Ten characteristics were arbitrarily chosen to assess the index of potential water retention capacity. If some of them do not show significant spatial variability, they may be excluded from the assessment (they increase the index value by the 
same constant for all subdivisions). Characteristics that would have identical spatial distributions might be excluded as well.

It was assumed in this paper that all characteristics would affect the index with the same strength. Still unanswered is the question if and which weights should be attributed to particular non-climatic physico-geographic characteristics.

\section{REFERENCES}

1. Cebulska M., Osuch B., 1998. Określenie zdolności intercepcyjnej mchu na przykładzie płonnika strojnego (Polytrichum attenuatum Menz). W: Las i woda. (Estimation of the interceptive ability of the moss Polytrichum attenuatum Menz. In: Forest and Water). Mater. Międzyn. Konf. Nauk. 25-29 maja 1998 r. Kraków, PKrak.: 271-279.

2. Flisowski J., Iwanejko R., Trzos O., Wieczysty A., Brzozo-WójciK M., 1986. Prognozowanie wpływu piętrzenia rzek na wody podziemne i obliczanie systemów odwadniających. (Prediction of the effect of river water lifting on ground waters and calculation of the draining systems). Kraków, PKrak.

3. GRAJEWSKI S., 2006. Stosunki wodne oraz zdolność retencyjna obszarów leśnych Parku Krajobrazowego Puszcza Zielonka. (Water relations and retention capacity of forest areas of the Landscape Park Puszcza Zielonka). Rozpr. Nauk. AR Pozn., 382: 92.

4. GUTRY-KORYCKA M., 1989. Intercepcja pokrywy roślinnej. W: Procesy hydrologiczne: fizycznogeograficzne podstawy modelowania. Red. U. Soczyńska. (Interception of plant cover. In: Hydrologic processes: physico-geographic bases of modelling. Ed. U. Soczyńska). Warszawa, PWN: 102-145.

5. Homa A., 1998. Retencja wody w ściółce leśnej. W: Las i woda. (Water retention in forest litter. In: Forest and Water). Mater. Międzyn. Konf. Nauk. 25-29 maja 1998 r. Kraków, PKrak.: 280-289.

6. Instrukcja urządzania lasu (Instructions for forest management), 1994. Warszawa, MOŚZNiL, DGLP.

7. KRYSZTOFIAK A., 2008. Stosunki wodne na obszarach mokradłowych w Leśnym Zakładzie Doświadczalnym Siemianice. (Water relations in wetlands of the Experimental Forest Farm Siemianice). Poznań, UP PhD-Thesis.

8. KRYSZTOFIAK A., GRAJEWSKI S., 2007. Potencjalna zdolność retencyjna obszarów leśnych Nadleśnictwa Doświadczalnego Siemianice. W: Melioracje wodne w kształtowaniu i ochronie środowiska. (Potential retention capacity of forest areas in the Experimental Forest Inspectorate Siemianice). Inż. Ekol, 8: 230-231.

9. Mapa hydrograficzna w skali 1:50 000; arkusze: M-34-25-C Byczyna, M-33-37-A Kluczbork, (Hydrographic map in the scale 1:50 000; sheets M-34-25-C Byczyna, M-33-37-A Kluczbork), 1998. Poznań, GEOPOL.

10. Mapa hydrograficzna w skali 1:50 000; arkusz M-34-25-A Wieruszów (sheet M-34-25-A Wieruszów), 2000. Poznań, GEOMAT Sp. z o.o.

11. Mapa przeglądowa siedlisk Nadleśnictwa Doświadczalnego Siemianice obrębu Wołczyn oraz obrębu Laski (Map of forest habitats in the Experimental Forest Inspectorate Siemianice, divisions Wolczyn and Laski), 1994. Skala 1:20 000. Poznań, BUL, GL.

12. Mapa topograficzna w skali 1:50 000 arkusze: M-34-25-C Połczyn, M-33-37-A Kluczbork, M-3425-A Wieruszów. (Topographic map in the scale 1:50 000, sheets M-34-25-C Połczyn, M-33-37-A Kluczbork, M-34-25-A Wieruszów). Opracowanie kartograficzne, 1997. Na podst. mapy kartograficznej w skali 1:10 000 stan aktualności 1993 r. Poznań, WPGK GEOMAP Sp. z o.o.

13. Miler A., 1984: Problem określania charakterystyk fizjograficznych zlewni jako podstawa oceny warunków retencyjnych. (The problem of estimating physiographic characteristics of catchment basins as a basis for assessing retention). W: Problematyka hydrologiczna i meteorologiczna małych zlewni rzecznych. Mater. Semin. Wrocław, PT Geofiz.: 16-28. 
14. Miler A., 1994. Modelowanie matematyczne zdolności retencyjnych małych zlewni nizinnych. (Mathematical modelling of retention capacities of small lowland catchment basins). Rocz. AR Pozn. Rozpr. Nauk., 258: 91.

15. Miler A., 1998. Modelowanie obszarowych zmienności różnych miar retencji. (Modelling spatial variability of various retention measures). Poznań, Wydaw. AR.

16. Miler A.T., GRAJEWSKI S., OKOŃSKI B., 2001. Stosunki wodne w wybranych ekosystemach Puszczy Zielonka. (Water relations in selected ecosystems of Puszcza Zielonka). Poznań, Wydaw. AR: 45.

17. Operat urządzenia gospodarstwa leśnego dla Nadleśnictwa Doświadczalnego Siemianice (Statement on forest farm management for the Experimental Forest Inspectorate Siemianice), 2005. Siemianice, LZD maszyn.

18. SULIŃSKI J., 1993. Modelowanie bilansu wodnego w wymianie między atmosfera, drzewostanem i gruntem przy użyciu kryteriów ekologicznych. (Modelling water balance in exchange between atmosphere, tree stand and soil using ecological criteria). Zesz. Nauk. AR Krak. Rozpr., 179.

19. StrZemski M., SiUtA J., WiteK T., 1973. Przydatność rolnicza gleb Polski. (Agricultural usefulness of soils in Poland). Warszawa, PWRiL: 133.

20. WŁOCZEWSKI T., 1968. Ogólna hodowla lasu. (General forest growing). Warszawa. PWRiL: 285.

\title{
STRESZCZENIE
}

\section{Potencjalna zdolność retencyjna obszarów leśnych na przykładzie Leśnictwa Doświadczalnego Unieszów}

\author{
Słowa kluczowe: Leśnictwo Doświadczalne Unieszów, miernik potencjalnej zdol- \\ ności retencyjnej, retencja wodna
}

W pracy zaproponowano, aby potencjalną zdolność retencyjną danego terenu, niekoniecznie zlewni, opisać za pomocą jednego parametru - miernika (wskaźnika), który ujmuje oddziaływanie wszystkich istotnych charakterystyk fizyczno-geograficznych nieklimatycznych w odniesieniu do rozpatrywanego obszaru. Podstawą szacowania wartości miernika potencjalnej zdolności retencyjnej obszarów zalesionych w tej metodzie jest wykorzystanie jako powierzchni elementarnej pododdziału, czyli najmniejszej jednostki przestrzennego podziału lasów i przydzielenie mu jednego parametru, uwzględniającego sumaryczne oddziaływanie najbardziej istotnych w danym regionie parametrów fizyczno-geograficznych na potencjalne zdolności retencyjne. Na tej podstawie każdemu z pododdziałów przyporządkowano charakterystyki, które uznano za determinujące jego potencjalną zdolność retencyjną. Następnie zakresy zmian wartości każdego z parametrów podzielono na trzy klasy, odpowiadające małej, średniej oraz dużej potencjalnej zdolności retencyjnej. Klasy te otrzymały odpowiednio kody „1”, „2” i „3”. W kolejnym kroku zsumowano kody wszystkich parametrów przypisanych każdemu pododdziałowi, w wyniku czego otrzymano dla każdego z nich nową wartość odzwierciedlająca jego zdolność retencyjną. Ostatnim etapem było wygenerowanie mapy przedstawiającej zmienność przestrzenną obliczonego miernika. Na podstawie spo- 
rządzonej mapy rozkładu miernika potencjalnej zdolności retencyjnej należy stwierdzić, że charakteryzuje się on znaczną zmiennością przestrzenną. Pododdziały o małej, jak i dużej potencjalnej zdolności retencyjnej, są rozrzucone po całym obiekcie bez wykazywania tendencji do łączenia się w większe płaty obszarowe. Wyniki przeprowadzonych badań mogą być podstawą do oceny stosunków wodnych, ustalenia hierarchii zadań w zakresie gospodarki wodnej w planach urządzania lasu czy planach zagospodarowania przestrzennego.

Received 08.12.2008

Reviewers:

Prof. Andrzej Ciepielowski

Prof. Waldemar Mioduszewski 